muscular work, either in or out of school, particularly if it involves postural fatigue. Risks of spinal curvature must be avoided, and the importance of adequate rest in a suitable position should receive careful consideration.

The onset of puberty must be recognized by the authorities through the characteristic wellmarked physical and mental changes, and due allowances made for it. During this period, especially in girls, ample provision should be made for a liberal dietary and well-balanced periods of exercise, rest and sleep.

It is a matter for regret that some authorities do not provide for medical inspection and treatment in Grammar Schools. The practice of medical inspection and treatment should be made universal, and medical officers should be encouraged to undertake a wider scope of inquiry. Meals should be available at all schools, and in arranging the dietary, the school medical staff should be consulted.

The psychological factors influencing the pupil in his mental development and his education should be studied continuously by the school teaching and school medical staff. These include the general characteristics of puberty and adolescence, mental and intellectual abilities, individual differences and special intellectual capacities, sensory capacities, attention, memory, imagery, reasoning, emotion, social impulses, self-assertion and submission, and so forth. In faet, the application of psychology to the study of the school child is of a special character, and therefore cannot be ignored. All trained teachers have received special instruction in this aspect of their careers, and this should make these problems less formidable than they would otherwise be, but it does not detract from their importance.

\title{
The Weather in Great Britain during 1938
}

\section{By E. G. Bilham}

GIR NAPIER SHAW, in the delightful Christmas card which his friends have been privileged to receive, describes the year 1938 as annus memorabilis. The description is a happy one, for the year was memorable in many respects. The amount of material available at the moment for the purpose of summing up the features of the year as a whole is relatively small, and we cannot here attempt anything in the nature of a detailed discussion. It has been thought, however, that a retrospect of the more striking meteorological events would be of interest.

The year began with a mild, wet and stormy January. In many parts of England and Wales no temperature below $32^{\circ} \mathrm{F}$. was recorded, and in most districts the mean for the month was about three degrees above normal. Gales were numerous, and that on January 14-16 was exceptionally severe. A gust of 101 miles per hour was recorded at St. Ann's Head on January 15. A similar velocity was reached at the Liverpool Observatory on January 29, and 100 miles per hour was also recorded in the Orkneys on January 23. A magnificent display of the aurora occurred on the night of January 25-26.

Conditions in respect to warmth and wind were less abnormal in February, but it produced one of those coincidences of tidal and meteorological conditions necessary for the occurrence of floods on the east coast of England. Such flooding occurs when a wind-induced deepening of the waters of the North
Sea, due to strong winds from the north-west quadrant, coincides with a high predicted tidal level. These conditions prevailed on the evening of February 12, when the sea burst over the lowlying coastland between Winterton and Palling in Norfolk and flooded an area of the order of fifteen square miles. Later, on April 3, the sea broke through the defences at Horsey and caused a further extensive inundation. The rainfall of February was very deficient except in parts of Scotland, the general fall over England and Wales being about half the normal.

The shortage of rainfall south of the Border was accentuated in March, when the general fall for England and Wales was only 27 per cent of the normal. It was the driest month of that name at many stations. On the other hand, parts of Scotland had excessive rainfall, as much as 50 inches being recorded at Loan (Loch Quoich). The month will also be remembered for its remarkable warmth. Previous records of mean temperature were exceeded by a substantial margin. For example, at the Radcliffe Observatory, Oxford, where records on a comparable basis are available back to 1815 , March 1938 gave a mean value exceeding the previous highest (1822, $47 \cdot 3^{\circ} \mathrm{F}$.) by as much as $2 \cdot 6^{\circ} \mathrm{F}$.

April continued the sequence of dry months. For the British Isles as a whole, it was the driest April on record, and probably the driest month of any name. The total rainfall of the three months 
February to April 1938 was less than that of any similar period back to 1785 . Some rural districts experienced an acute shortage of water. Severe frosts during the periods April 9-11 and again about April 18-19 caused much damage to the blossom and buds of fruit crops.

There were further damaging frosts in the early days of May, the reading of the screened minimum thermometer being as low as $18^{\circ} \mathrm{F}$. on May 8 at Thetford, Norfolk. A week later a temperature as high as $79^{\circ} \mathrm{F}$. was registered at Norwich and Canterbury. June was rendered noteworthy by the great gale on June 1-2, during which the gusts recorded on the south coast were comparable with those of severe winter storms. This storm produced a remarkable discoloration of foliage of trees in the south of England, due probably to the combined effects of buffeting and salt spray borne inland by the wind.

July was a wet month, with a very marked deficiency of sunshine. A very heavy rainfall occurred in the English Lake District on July 29 ; the reading amounted to 5.95 in. at Watendlath Farm and to $5 \cdot 60$ in. at Borrowdale.

The first day of August was the warmest of the year, $87^{\circ} \mathrm{F}$. being recorded in London on that day. Thunderstorms were frequent and severe during August. During one of these the remarkable rainfall of $6 \cdot 39$ in. occurred at Torquay on Aug. 4.
The early autumn was relatively uneventful, but November was remarkable for exceptional warmth in all districts. On November $5,70^{\circ} \mathrm{F}$. was registered in many parts of east and southeast England. The mean temperature of the month, $49 \cdot 3^{\circ} \mathrm{F}$., was the highest in November at Oxford since 1818. A very severe gale occurred on November 23, the gust velocity reaching 108 miles per hour at St. Ann's Head ; 98 miles per hour was registered at Stornoway on November 18.

The abnormal warmth was maintained during the first half of December. There was an abrupt change on December 17, when Great Britain began to be affected by very cold air spreading eastward from the continent of Europe. The wintry conditions lasted over the Christmas holiday period and the southern districts thus experienced the unusual phenomenon of a 'white Christmas'. At Manston, Thanet, during the period December 1724, temperature remained continuously below freezing point for 147 hours, and at Lympne, Kent, similar conditions persisted for 222 hours, apart from a break of a few hours on December 24. At the latter station the maximum temperature on December 20 was no higher than $22^{\circ} \mathrm{F}$. Although the period was certainly the most severe since February 1929, the extreme minimum temperatures were not specially remarkable, the lowest so far reported being $7^{\circ} \mathrm{F}$. at Dalwhinnie on December 19.

\section{Obituary Notices}

Prof, George Barger, F.R.S.

THE sudden death on January 6 of Prof. George Barger, at the early age of sixty years, has come as a shock to all those, in many countries, who were his friends. Barger was born in Manchester in 1878, his father being Dutch, his mother English; and his childhood in a bilingual home, followed by schooling in Holland, laid the basis of that easy fluency in many languages which so distinguished him in later life. He returned to his native England for his university courses, entering King's College, Cambridge, with a scholarship in natural science, after a year at University College, London. In 1904 he was elected a fellow of King's College.

The fact that Barger was placed in the first class in both botany and chemistry in Part II of the Natural Sciences Tripos seemed to leave the direction of his life's work in doubt; but, though his first appointment was as demonstrator in botany in Brussels, under the late Prof. Errera, the researches which he there began were essentially chemical, and included an ingenious and useful method of determining molecular weights on very small samples, by the comparative measurement of the vapour pressures of solutions. His next appointment was as chemist to the Wellcome Physiological Research Laboratories, where he had already begun some chemical fractionations of the constituents of ergot, when I became associated with him, in 1904, in a collaboration extending over five active and happy years.

The first stage culminated in 1906 with the isolation by Barger, with F. H. Carr, of the alkaloid ergotoxine, which cleared the subject of a confusing competition of impure 'principles', and opened the way to the discovery by others of a series of related alkaloids, extending over the intervening years to the present day. Then came the recognition in ergot extracts of a series of simple, active amines derived from amino acids; tyramine first, and Barger's synthesis of a series of 'sympathomimetic' amines leading from tyramine to adrenaline; and later histamine, which Barger also first isolated from an animal (intestinal) extract, thus opening the way to important chapters in physiology and pathology. Another simple base which has recently figured prominently in physiological conceptions, acetylcholine, was found a few years later in an ergot extract by Barger's former pupil and co-worker, A. J. Ewins, after Barger himself had gone to an academic appointment in chemistry at the Goldsmiths' College, Lewisham, from which, after some years, he passed to the chair of chemistry at the Royal Holloway College, London. 